\title{
KONTRIBUSI STABILITAS EMOSI TERHADAP KEMAMPUAN PEMBUATAN KEPUTUSAN KARIER SISWA SMP
}

\begin{abstract}
Ahmad Fajri ${ }^{1}$
Abstract: Contributions Emotion Stability to Career Decision Making Ability of SMP Students. This research is motivated by the career decision-making abilities of students of class IX are still easily influenced by the environment, it is because students feel anxious not appropriate selection of subsequent studies. Identified emotion stability can provide a positive influence on career decision-making abilities, like not anxious, to understand the feelings of others, and is able to accept the other person's perspective. In general the studies carried out to determine the contribution of emotion stability to the career decision-making abilities of students class IX SMPN 26 Bandung Academic Year 2016/2017. The research approach using a quantitative approach to the study correlational. The samples used were all students of class IX SMPN 26 Bandung academic year of $2016 / 2017$ as many as 286 people. The results showed that (1) the emotion stability of students that are in the category of less stable with a percentage of $66.4 \%$, (2) the ability of making career decisions of students in the category capable with a percentage of $53.5 \%$, (3) there is a positive contribution and significant emotion stability of $16.7 \%$ against the career decision-making abilities of students, meaning that the diversity of career decision-making ability scores of students of class IX SMPN 26 Bandung determined by emotion stability student of $16.7 \%$. The results of this analysis can be considered state aid students in the focus of guidance and counseling services.
\end{abstract}

Keywords: Career Decision-Making Abilities, Emotion Stability.

INDONESIAN JOURNAL OF EDUCATIONAL COUNSELING

Website: http://ojs.ejournal.id/index.php/ijec

Permalink: http://ojs.ejournal.id/index.php/ijec/article/view/123

How to cite (APA): Fajri, A. (2017). Kontribusi stabilitas emosi terhadap kemampuan pembuatan keputusan karier siswa SMP. Indonesian Journal of Educational Counseling, 1(2), 179-196.

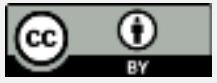

This is an open access article distributed under the terms of the Creative Commons Attribution 4.0 International License, which permits unrestricted use, distribution, and reproduction in any medium, provided the original work is properly cited.

\section{PENDAHULUAN}

Peserta didik pada jenjang Sekolah Menengah Pertama secara psikologis telah memasuki masa perkembangan remaja madya, karena berada pada rentang usia 15-18 tahun (Monks, dkk dalam Desmita 2006: 192). Pada masa ini peserta didik memiliki reaksi dan ekspresi emosi yang masih cenderung labil serta kecenderungan minat dan pilihan karier yang sudah relatif lebih jelas. Menurut Ali dan Asrori (2009: 10) pada masa remaja individu mengalami

\footnotetext{
${ }^{1}$ Departemen Psikologi Pendidikan dan Bimbingan, FIP Universitas Pendidikan Indonesia.
} 
perkembangan yang sangat potensial, baik dari aspek kognitif, emosi maupun fisik.

Remaja merupakan salah satu rentang kehidupan manusia, pada masa ini individu dihadapkan dengan tugas perkembangan yang harus dituntaskan. Menurut Yusuf (2011: 71) remaja memiliki tugas-tugas perkembangan yang diarahkan perkembangan masa dewasa yang sehat. Kartadinata, dkk (2013: 13) mengemukakan tugas perkembangan remaja di Indonesia termasuk peserta didik di SMP adalah

"mengenal kemampuan, bakat, minat serta arah kecenderungan karier dan apresiasi seni, dan mengembangkan pengetahuan dan keterampilan sesuai dengan kebutuhannya untuk mengikuti dan melanjutkan pelajaran/atau mempersiapkan karier serta berperan dalam kehidupan masyarakat."

Pada tahap perkembangan karier, menurut Super (Suherman, 2013: 78), peserta didik usia Sekolah Menengah Pertama berada pada tahap eksplorasi. Sejalan dengan pendapat Super, tahap eksplorasi karier pada peserta didik SMP menurut Murro dan Kottman (1995: 352) lebih cenderung kepada mengeksplorasi minat dan bakatnya serta mulai membuat keputusan penting tentang pendidikan yang memberikan pengaruh terhadap keputusan karier. Hal ini berarti bahwa tahapan eksplorasi yang sedang dijalani oleh peserta didik SMP ditandai dengan mulai melakukaan penelaahan diri baik itu kemampuan dan kelemahan yang dimilikinya dan membuat sebuah keputusan tentang studi lanjutan.

Menurut Gati dan Saka (2001), membuat sebuah keputusan yang berhubungan dengan masa depan merupakan sesuatu yang kompleks dan sulit, terlebih bagi seorang remaja. Hal ini berarti bahwa pembuatan keputusan dalam hal pilihan studi lanjutan oleh peserta didik merupakan sesuatu yang tergolong tidak mudah dilakukan. Crites (Suherman, 2013: 83) yang mengemukakan bahwa keputusan karier yang dibuat oleh peserta didik seringkali tanpa mempertimbangkan minat, pemahaman tentang pilihannya dan nilai. Berdasarkan hal tersebut pembuatan keputusan berupa pilihan studi lanjutan setelah SMP merupakan sesuatu yang sulit jika peserta didik tidak mempertimbangkan minat dan kemampuan yang dimilikinya.

Hasil penelitian Zamroni, Sugiharto, \& Tadjri (2014: 2) pada kelas IX SMP 1 Dawe Kudus menemukan bahwa sebagian besar peserta didik masih kurang mampu memahami potensi yang dimilikinya. Selain itu, Yulius (2014: 5) menemukan bahwa sebagian besar peserta didik kelas IX di SMP Negeri 9 Salatiga masih mengalami kesulitan dan kebingungan dalam membuat keputusan karir berupa memilih studi lanjutan setalah menamatkan pendidikan di SMP. Badan Pusat Statistik (BPS) mencatat pada bulan Agustus 2014, 
jumlah seluruh pengangguran di Indonesia sebanyak 7.240.000 orang, dari jumlah itu sebanyak 7,15\% berasal dari lulusan SMP. Berdasarkan beberapa penelitian dan temuan diatas, menunjukan bahwa peserta didik SMP masih belum mampu dalam membuat keputusan karier yang tepat.

Penelitian Ragasukmasuci (2013) pada siswa kelas IX SMP Negeri 9 Bandung menemukan bahwa sebesar $79 \%$ peserta didik masih bingung dalam memilih sekolah lanjutan, sebesar $71 \%$ peserta didik belum mampu mengatasi sendiri masalah yang dihadapi ketika memilih sekolah lanjutan dan sebesar $72 \%$ peserta didik belum berani mengungkapkan ide atau gagasan tentang sekolah lanjutan yang diinginkan. Hal ini berarti sebagian besar permasalahan yang dialami oleh peserta didik dalam membuat keputusan karier berupa kebingungan dalam memilih studi lanjutan.

Keputusan karier yang dibuat peserta didik seringkali masih bergantung kepada pilihan orang tua dan belum mampu membuat keputusan yang berdasarkan pemahaman tentang dirinya sendiri. Hal ini diperkuat dengan temuan Budiamin (2002: 259-266) menunjukan bahwa sebagian besar 90\% peserta didik SMU di kabupaten Bandung masih mengalami kebingungan dalam memilih karier, dan $70 \%$ peserta didik menyatakan perencanaan masa depan tergantung pada pilihan orang tua.

Selain hasil penelitian diatas, beberapa ahli menyimpulkan tentang permasalahan dalam pembuatan keputusan peserta didik. Menurut Manrihu (1988: 114) permasalahan yang sering dialami oleh peserta didik SMP adalah memilih sekolah lanjutan yang akan dimasuki dan memilih jurusan-jurusan di sekolah lanjutan atas. Secara lebih rinci, Suherman (2013: 83-84) menjelaskan terdapat delapan permasalah yang dialami peserta didik jika mengacu pada teori perkembangan karier Super yaitu: 1) tidak mampu merencanakan karir dengan baik; 2) kurang berusaha mengeksplorasi karir; 3) Pengetahuan tentang membuat keputusan karir yang kurang memadai; 4) kurang memiliki pengetahuan tentang dunia kerja; 5) pengetahuan tentang kelompok pekerjaan yang disukai yang kurang memadai; 6) kesenjangan antara kemampuan diri dengan pilihan karir; 7) orientasi karir yang kurang memadai; 8) terdapat stereotype gender.

Pembuatan keputusan peserta didik SMP lebih diarahkan kepada kemampuan menentukan studi lanjutan setelah lulus SMP. Keputusan karier tentang studi lanjutan yang dipilih oleh peserta didik sebagian besar terjadi dalam situasi yang menegangkan dan kurang nyaman sehingga melibatkan kondisi emosi peserta didik dalam pembuatan keputusan kariernya. Hal ini dapat mengganggu keputusan karier yang dibuat jika kondisi emosi peserta didik berada dalam kondisi yang tidak stabil. 
Peran emosi dalam membuat keputusan karier diperkuat oleh pendapat Gadassi, Gati, \& Wagman-Rolnick (2013: 493) yang mengemukakan bahwa faktor emosi memegang peran yang penting dalam pembuatan keputusan karier. Faktor emosi yang meliputi pandangan pesimis, perasaan cemas, serta konsep diri individu dapat menyebabkan kesulitan dalam membuat keputusan karir. Hal ini dapat dipahami ketika peserta didik merasa cemas dengan keputusan studi lanjutannya setelah SMP, karena merasa bahwa pilihannya bukan yang terbaik dan dapat mengecewakan orang disekitarnya, terutama orangtua. Hal ini memicu keputusan karier mengenai studi lanjutan setelah SMP diserahkan sepenuhnya kepada orangtua. Selain itu, peserta didik merasa bahwa pilihan studi lanjutannya bukan merupakan keputusan yang baik karena dibayangi kegagalan dalam mencapai tujuannya dalam pilihan studi lanjutan. Hal ini membuat peserta didik mudah terpengaruh oleh lingkungannya, terutama teman sebaya.

Sejalan dengan pendapat Gadassi, Gati, \& Wagman-Rolnick di atas, Mardi Lestari (2015) menemukan bahwa kemampuan pembuatan keputusan karier dalam memilih kelanjutan studi peserta didik kelas IX SMP masih mudah dipengaruhi oleh teman dan perintah orang tua. Selain itu, Yuan (1998: 67) menyatakan bahwa orang tua dan teman adalah memiliki pengaruh dalam pembuatan karir peserta didik di kota Shanghai, Edinburgh, dan Hongkong. Hal tersebut menggambarkan bahwa peserta didik belum mampu membuat keputusan karier yang sesuai dengan dirinya, dengan mudah terpengaruh oleh lingkungan ketika pada pilihan karier.

Menurut Blau (Sukardi, 1987: 88) pilihan seseorang terhadap suatu pekerjaan di dorong oleh faktor keinginan untuk mendapat ganjaran dan faktor pengharapan terhadap perubahan. Hal ini dapat terjadi saat peserta didik membuat pembuatan keputusan tentang studi lanjutan, ketika dihadapkan pada pilihan peserta didik tidak hanya mengharapkan sebuah hasil yang baik dari pilihannya tetapi dibayangi oleh perasaan cemas dan tidak percaya diri pada keputusan yang dibuatnya. Hal ini didukung dengan pendapat Savickas (Gadassi, Gati, \& Wagman-Rolnick, 2013: 493) bahwa perasaan cemas dan permasalahan emosi lainnya dapat mempengaruhi keputusan karier. Perasaan cemas dan takut yang dirasakan peserta didik dalam membuat keputusan dapat membuat tidak yakin dan mudah dipengaruhi oleh lingkungan.

Smithson (Dissanayake \& Gunaseakre, 2016: 3) memandang stabilitas emosi sebagai salah satu cara memahami secara seimbang permasalahanpermasalahan yang dialami. Menurut Hurlock (2002: 214) Stabilitas emosi pada usia remaja merupakan keseimbangan dan kemantapan remaja dalam memahami, mengendalikan, mengungkapkan, dan menyesuaikan perasaan secara mandiri. Fabio (2013: 57) menambahkan bahwa seseorang yang 
mampu mengelola respon emosional mereka dapat membuat keputusan yang lebih baik. Hal ini berarti bahwa individu dengan stabilitas emosi yang baik akan mampu memahami sebuah permasalahan dan memiliki pilihan tindakan yang digunakan sebagai upaya dalam mengatasi permasalahan dengan tepat.

Sejalan dengan pendapat tersebut, Dissanayake dan Guaseakre (2016: 4-5) memandang bahwa stabilitas emosi tinggi yang dimiliki individu akan membuat individu tersebut tidak mudah dipengaruhi oleh stimulus yang datang dari luar maupun dalam dirinya. Stabilitas yang dimiliki oleh individu dapat mendorong individu tersebut mampu dengan mudah menyesuaikan diri dengan lingkungannya dan tidak menunjukan ketegangan emosional.

Irma (Widanti, 2015: 124) menjelaskan bahwa individu dengan stabilitas emosi yang baik akan menunjukan emosi yang tetap. Individu dengan stabilitas emosi yang baik mampu dalam mengendalikan perilaku pada situasi-situasi yang kurang menyenangkan dan terlalu menyenangkan. Sebaliknya, individu yang stabilitas emosinya kurang baik akan memiliki kecenderungan perubahan emosi yang cepat dan tidak mudah dikendalikan.

Penelitian Chotimah (2010) mengenai stabilitas emosi terhadap 320 peserta didik kelas X SMA Negeri 1 Karanganom menunjukan rata-rata stabilitas emosi peserta didik sebesar $78 \%$. Selain itu, penelitian lain yang menunjukan stabilitas emosi dilakukan oleh Sari (2013) mengenai stabilitas emosi peserta didik kelas VIII SMP Yayasan Atikan Sunda sebanyak 252 orang, hasilnya menunjukan bahwa $88,9 \%$ peserta didik berada pada kategori cukup stabil, namun memiliki kecenderungan peserta didik masih mudah terpengaruh oleh lingkungan sekitarnya. Hal ini menunjukan bahwa kondisi stabilitas emosi peserta didik cukup baik yang ditunjukan dengan tetap tenang pada situasi yang kurang kondusif.

Menurut Gadassi, Gati, \& Wagman-Rolnick (2013: 493) kendala emosi dapat menghambat dalam proses pembuatan keputusan karir seseorang. Stabilitas emosi dapat mempengaruhi kemampuan peserta didik dalam pembuatan keputusan karier, karena peserta didik akan sulit menyadari kemampuan dirinya dan cenderung mengikuti perintah orang lain.

Pemaparan di atas menggambarkan permasalahan stabilitas emosi dan pembuatan keputusan karir pada peserta didik sekolah menengah pertama. Stabilitas emosi diperlukan ketika membuat sebuah keputusan karir, hal ini agar peserta didik dalam memilih studi lanjutan dapat mempertimbangan berbagai informasi, baik itu tentang potensi yang pada dirinya seperti minat, bakat, kepribadian, serta informasi mengenai pilihan studi lanjutannya. Peserta didik dengan stabilitas emosi yang rendah memiliki kecenderungan untuk mengikuti lingkungan, baik itu teman atau perintah orang tua dalam membuat 
keputusan karir tanpa mempertimbangan kemampuan yang dimilikinya dan informasi karir yang ingin dicapainya.

\section{METODE}

Penelitian ini menggunakan metode deskriptif dengan jenis studi korelasi. Arifin (2011: 54) menjelaskan bahwa metode deskriptif adalah suatu metode penelitian yang bertujuan untuk mendeskripsikan dan menjawab persoalanpersoalan suatu fenomena atau peristiwa yang terjadi, baik tentang fenomena dalam variabel tunggal maupun korelasi dan atau perbandingan berbagai variabel. Penelitian deskriptif ini menghasilkan informasi yang tepat dan gambaran secara sistematis, faktual, dan akurat (Sukmadinata, 2013: 54).

Penggunaan metode deskriptif bertujuan untuk mendapatkan gambaran umum stabilitas emosi dan kemampuan pembuatan keputusan karier serta mendapatkan deskripsi mengenai kontribusi stabilitas emosi terhadap kemampuan pembuatan keputusan karier peserta didik kelas IX SMP Negeri 26 Bandung Tahun Ajaran 2016/2017.

Studi korelasional yang digunakan dalam penelitian ini adalah ukuran statistik yang menyatakan derajat hubungan antara dua variabel atau lebih (Usman \& Akbar, 2000: 197). Teknik korelasi digunakan untuk mengetahui kontribusi stabilitas emosi terhadap pembuatan keputusan karier peserta didik serta menyatakan ukuran derajat hubungan stabilitas emosi dengan pembuatan keputusan karier peserta didik.

Pemilihan metode deskriptif korelasional dalam penelitian ini didasarkan atas tujuan penelitian yang ini mengetahui dan menganalisa nilai kontribusi stabilitas emosi terhadap kemampuan pembuatan keputusan karier pada siswa kelas IX SMP Negeri 26 Bandung Tahun Ajaran 2016/2017.

Populasi dalam penelitian ini adalah seluruh peserta didik kelas IX SMP Negeri 26 Bandung Tahun Ajaran 2016/2017. Sampel dalam penelitian ini berjumlah 283 peserta didik yang tersebar di kelas IX-A sampai dengan IX-H.

Instrumen pengungkap data stabilitas emosi dan pembuatan keputusan karier yang digunakan dalam penelitian ini diadaptasi dan modifikasi dari instrumen yang dikembangkan oleh Ananda Rachmaniar (2015) dan Pia Arina Iskandar (2015). Instrumen kemandirian menggunakan skala Likert yang terdiri dari lima pilihan jawaban yaitu sangat sesuai (SS), sesuai (S), kurang sesuai (KS), tidak sesuai (TS), sangat tidak sesuai (STS).

Data yang telah diperoleh dari instrumen stabilitas emosi dan kemampuan pembuatan keputusan karier, selanjutnya dikelompokan menjadi menjadi tiga kategori. Kategori untuk stabilitas emosi, yaitu stabil, kurang stabil, dan tidak 
stabil, adapun untuk kategori kemampuan pembuatan keputusna karier, yaitu mampu, cukup mampu, dan tidak mampu. Penentuan kategorisasi stabilitas emosi dan kemampuan pembuatan keputusan karier dilakukan dengan mencari skor idealnya.

Instrumen yang telah disusun, perlu diujikan agar mendapatkan instrumen yang valid dan reliabel. Berdasarkan hal tersebut maka dilakukan tahapan untuk memperoleh instrument yang valid dan reliabel yaitu uji validitas rasional, uji keterbacaan, uji validitas item, uji reliabilitas.

Penelitian ini menggunakan teknik analisis yang digunakan adalah analisis korelasi. Analisis data yang akan digunakan dalam penelitian ini adalah uji korelasi Spearman rho dengan rumus:

$$
r s=1-\frac{6 \sum d^{2}}{n\left(n^{2}-1\right)}
$$

Keterangan:

rs : koefisien korelasi spearman

$\sum d^{2} \quad$ : total kuadrat selisih antar ranking

n : jumlah sampel

\section{HASIL DAN PEMBAHASAN}

Gambaran umum stabilitas emosi peserta didik kelas IX SMP Negeri 26 Bandung menunjukan bahwa sebanyak 91 orang peserta didik $(31,8 \%)$ berada pada kategori stabil, 109 orang peserta didik $(66,4 \%)$ berada pada kategori kurang stabil, dan 5 orang peserta didik $(1,7 \%)$ berada pada kategori tidak stabil. Hal ini berarti bahwa pada umumnya peserta didik kelas IX SMP Negeri 26 Bandung Tahun Ajaran 2016/2017 memiliki emosi yang kurang stabil dan masih belum konsisten dengan sikap yang ditunjukan dalam kehidupan seharihari.

Secara lebih rinci, hasil temuan pada setiap aspek stabilitas emosi, tingkat ketercapaian peserta didik dalam aspek pengungkapan emosi sebesar 38,1\% berada pada kategori stabil, sebesar $57,3 \%$ berada pada kategori kurang stabil, dan sebesar $4,5 \%$ berada pada kategori tidak stabil. Hal ini berarti bahwa peserta didik kelas IX SMP Negeri 26 Bandung Tahun Ajaran 2016/2017 telah belum mampu mengungkapkan emosi secara baik-baik, namun sudah mampu mengetahui perasaan yang sedang dialaminya.

Tingkat ketercapaian peserta didik dalam aspek pengendalian emosi sebesar $41,3 \%$ berada pada kategori stabil, sebesar $55,9 \%$ berada pada kategori 
kurang stabil, dan sebesar $2,8 \%$ berada pada kategori tidak stabil. Hal ini berarti bahwa peserta didik kelas IX SMP Negeri 26 Bandung Tahun Ajaran 2016/2017 telah mampu menenangkan diri dengan mengatasi dorongan emosi yang muncul, namun masih sering merasa cemas.

Tingkat ketercapaian peserta didik dalam aspek kesesuaian antara diri dengan lingkungan sebesar $45,1 \%$ berada pada kategori stabil, sebesar $52,4 \%$ berada pada kategori kurang stabil, dan sebesar 2,4\% berada pada kategori tidak stabil. Hal ini berarti bahwa peserta didik kelas IX SMP Negeri 26 Bandung Tahun Ajaran 2016/2017 mulai mampu menunjukan tindakan secara tepat dalam mengatasi masalah dan mulai mampu berusaha untuk menyesuaikan diri dengan lingkungan sekitar pada situasi dan kondisi yang tepat.

Gambaran umum kemampuan pembuatan keputusan karier peserta didik kelas IX SMP Negeri 26 Bandung menunjukan bahwa sebanyak 153 orang peserta didik $(53,50 \%)$ berada pada kategori mampu, 128 orang peserta didik $(44,76 \%)$ berada pada kategori cukup mampu, dan 5 orang peserta didik $(1,75 \%)$ berada pada kategori tidak mampu. Hal ini berarti bahwa secara umum peserta didik kelas IX SMP Negeri 26 Bandung Tahun Ajaran 2016/2017 telah memiliki kemampuan pembuatan keputusan karier yang baik. Peserta didik kelas IX telah mampu mengetahui kemampuan dan kelemahan yang dimilikinya, memiliki keyakinan bahwa pilihan kariernya merupakan pilihan tepat, dan telah mampu menggunakan pengetahuan dan pemikiran dalam membuat keputusan serta bertanggung jawab atas keputusannya.

Secara lebih rinci, hasil temuan pada setiap aspek kemampuan pembuatan keputusan karier bahwa tingkat ketercapaian peserta didik dalam aspek pengetahuan sebesar $69,93 \%$ berada pada kategori mampu, sebesar 27,97\% berada pada kategori cukup mampu, dan sebesar $2,1 \%$ berada pada kategori tidak mampu. Hal ini berarti bahwa peserta didik kelas IX SMP Negeri 26 Bandung Tahun Ajaran 2016/2017 mampu untuk memahami diri, peserta didik mengetahui kelemahan dan kelebihan diri berikut minatnya, peserta didik memahami tujuan karir, peserta didik mampu untuk mengetahui lingkungan karir yang efektif bagi dirinya.

Tingkat ketercapaian peserta didik dalam aspek sikap sebesar $68,88 \%$ berada pada kategori mampu, sebesar $28,67 \%$ berada pada kategori cukup mampu, dan sebesar $2,45 \%$ berada pada kategori tidak mampu. Hal ini berarti bahwa peserta didik kelas IX SMP Negeri 26 Bandung Tahun Ajaran 2016/2017 memiliki keyakinan diri bahwa peserta didik mampu untuk membuat keputusan karir yang tepat, peserta didik memiliki keterlibatan diri yakni menjalani aktivitas yang menunjang terhadap pilihan karier. 
Tingkat ketercapaian peserta didik dalam aspek keterampilan sebesar $36,71 \%$ berada pada kategori mampu, sebesar $60,14 \%$ berada pada kategori cukup mampu, dan sebesar $3,15 \%$ berada pada kategori tidak mampu. Hal ini berarti bahwa peserta didik kelas IX SMP Negeri 26 Bandung Tahun Ajaran 2016/2017 cukup mampu untuk menggunakan pengetahuan dan pemikiran dalam membuat keputusan, belum mampu bertanggung jawab atas keputusan yang telah dibuat dengan tidak memiliki rencana alternatif, dan masih bergantung pada bantuan orang lain namun siap dengan konsekuensi dari pilihan yang telah dibuat.

Kontribusi stabilitas emosi terhadap kemampuan pembuatan keputusan karier dapat diketahui dengan melakukan uji korelasi menggunakan analisis Spearman rho. Berdasarkan hasil uji korelasi, nilai korelasi antara stabilitas emosi dengan kemampuan pembuatan keputusan karier yaitu sebesar 0.409. Menurut Sugiyono (2012: 184), nilai korelasi sebesar 0.409 termasuk dalam kategori sedang.

Hipotesis dalam penelitian ini adalah bahwa stabilitas emosi berkontribusi positif terhadap kemampuan pembuatan keputusan karier. Adapun rumusan hipotesisnya adalah sebagai berikut:

$$
\begin{aligned}
& \mathrm{H}_{0}: P=0 \\
& \mathrm{H}_{1}: P>0
\end{aligned}
$$

Dengan menggunakan taraf signifikansi $(\alpha)=0,05$, maka kriteria pengujian hipotesisnya yaitu, Tolak $\mathrm{H}_{0}$ jika $P<\alpha$. Nilai signifikansi yang diperoleh adalah 0,0001 , artinya koefisien korelasi dinyatakan signifikan. Kesimpulan hipotesis yang didapat adalah $\mathrm{H}_{0}$ ditolak dan $\mathrm{H}_{1}$ diterima, karena $P=0,0001<0,05$.

Nilai kontribusi stabilitas emosi terhadap kemampuan pembuatan keputusan karier peserta didik kelas IX SMP Negeri 26 Bandung Tahun Ajaran 2016/2017, dapat diketahui melalui koefisien determinasi (KD), berikut adalah rumus yang digunakan untuk menghitung koefisien determinasi.

$\mathrm{KD}=r_{x y}^{2} X 100 \%$

Keterangan:

KD :Koefisien Determinasi;

$r_{x y}$ : Koefisien korelasi

$\mathrm{KD}=r_{x y}^{2} X 100 \%$

$=(0,409)^{2} \times 100 \%$

$=16,7281 \times 100 \%$

$=16,7 \%$ 
Berdasarkan hasil perhitungan, menunjukan bahwa keragaman skor kemampuan pembuatan keputusan karier peserta didik kelas IX SMP Negeri 26 Bandung Tahun Ajaran 2016/2017 ditentukan oleh stabilitas emosi sebesar $16,7 \%$, sedangkan sisanya sebesar $83,3 \%$ ditentukan oleh faktor lain selain stabilitas emosi. Hal ini berarti bahwa stabilitas emosi berkontribusi positif dansignifikan terhadap kemampuan pembuatan keputusan karier peserta didik kelas IX SMP Negeri 26 Bandung. Kekuatan hubungan yang terjadi berada pada kategori sedang, ini berarti bahwa peserta didik yang stabil emosinya cenderung memiliki kemampuan pembuatan keputusan karier yang baik. Sebaliknya, peserta didik yang mampu membuat keputusan karier cenderung memiliki emosi yang stabil.

Hubungan antara stabilitas emosi dengan kemampuan pembuatan keputusan karier positif, artinya bahwa kemampuan pembuatan keputusan karier, salah satunya ditentukan oleh stabilitas emosi.

Berdasarkan data hasil penelitian menunjukan bahwa gambaran umum stabilitas emosi peserta didik kelas IX SMP Negeri 26 Bandung memiliki kecenderungan emosi yang termasuk kategori kurang stabil sebesar 66,4\%. Hal ini menunjukan bahwa tingkat kecenderungan stabilitas emosi sampel penelitian masih belum optimal, sehingga masih dapat ditingkatkan. Peserta didik memiliki emosi yang kurang stabil masih belum konsisten dengan sikap yang ditunjukan dalam kehidupan sehari-hari sehingga peserta didik masih rentan terpengaruh oleh lingkungan sekitar ketika membuat keputusan kariernya, hal ini memiliki dampak negatif bagi peserta didik karena akan membuat peserta didik bergantung pada orang lain saat membuat keputusan untuk dirinya sendiri.

Hasil ini sejalan dengan temuan Sari (2013) tentang stabilitas emosi di SMP Yayasan Atikan Sunda, sebesar $88,9 \%$ siswa berada dalam kategori emosi yang kurang stabil. Menurut Sherman (Irawati, 2003: 17), stabilitas emosi pada remaja pada dasarnya adalah ketika remaja tersebut mampu untuk mengungkapkan dan memahami perasaan, mengendalikan emosinya, mandiri secara emosi, mampu menyesuaikan diri, mampu menyelesaikan masalah, ramah, dan hormat kepada diri sendiri dan orang lain.

Berdasarkan hasil analisis, stabilitas emosi peserta didik kelas IX SMP Negeri 26 Bandung berada pada kategori kurang stabil, artinya peserta didik kelas IX SMP Negeri 26 Bandung secara umum memiliki kecenderungan emosi yang belum optimal, sehingga mudah terpengaruh oleh kondisi lingkungan sekitarnya.

Hal tersebut sesuai dengan pendapat Hurlock (2002: 212) yang menyebutkan bahwa kestabilan emosi seseorang dipengaruhi oleh fisik, kondisi lingkungan, 
dan faktor pengalaman dirinya. Hurlock menambahkan bahwa sebagian besar remaja mengalami ketidakstabilan emosi dari waktu ke waktu akibat dari usahanya dalam menyesuaikan diri dengan pola perilaku dan harapan sosial. Hal ini termasuk kedalam faktor individu yang dapat mempengaruhi stabilitas emosi. Sejalan dengan pendapat tersebut, Hiremani (Singh, Kaur, \& Dureja, 2012: 41) menyebutkan bahwa keadaan orang tua dan kondisi lingkungan sosiokultural mempengaruhi stabilitas individu.

Hasil temuan pada tiap aspek stabilitas emosi, yaitu aspek pengungkapan emosi, aspek pengendalian emosi, dan aspek kesesuaian antara diri sendiri dengan lingkungan berada pada kategori kurang stabil. Dari ketiga aspek yang ada, aspek pengungkapan emosi memiliki persentase paling tinggi yakni sebesar $57,3 \%$ pada kategori kurang stabil.

Hal ini dapat dipahami karena dalam mengungkapkan emosinya, seseorang memiliki pertimbangannya sendiri agar emosi yang diungkapkannya tepat dengan kondisi yang sedang dihadapinya. Menurut Gunarsa (Latifa, 2012) dalam mengungkapkan emosi, seseorang akan cenderung berhati-hati terhadap dirinya dan hubungannya dengan membatasi pikiran dan perasaanperasaan yang dikemukakannya. Lebih lanjut Latifa (2012) menjelaskan bahwa terdapat beberapa hal yang mempengaruhi seseorang dalam mengungkapkan emosinya, yakni bentuk peristiwa yang terjadi, evaluasi terhadap situasi, perubahan fisiologisnya, tendensi tindakannya, regulasi, kondusif atau tidaknya lingkungan dan pengalaman emosi yang pernah dialaminya.

Kemampuan pembuatan keputusan karier dalam penelitian ini diartikan sebagai kemampuan peserta didik dalam memilih studi lanjutan setelah lulus SMP. Aspek-aspek yang diungkap untuk mengetahui gambaran umum kemampuan pembuatan keputusan karier adalah pengetahuan, sikap, dan keterampilan

Berdasarkan temuan penelitian menunjukan bahwa secara umum kemampuan pembuatan keputusan karier peserta didik kelas IX SMP Negeri 26 Bandung Tahun Ajaran 2016/2017 berada pada kategori mampu sebesar 53,3\% Hal ini ditunujukan dengan peserta didik yang mampu membuat keputusan karier dengan a) mampu untuk memahami diri, peserta didik mengetahui kelemahan dan kelebihan diri berikut minatnya, peserta didik memahami tujuan karier, peserta didik mampu untuk mengetahui lingkungan karir yang efektif bagi dirinya, b) memiliki keyakinan diri bahwa peserta didik mampu untuk membuat keputusan karier yang tepat, peserta didik memiliki keterlibatan diri yakni menjalani aktivitas yang menunjang terhadap pilihan karir, dan c) mampu untuk menggunakan pengetahuan dan pemikiran dalam membuat keputusan, serta 
bertanggung jawab atas keputusan yang telah dibuat dengan memiliki rencana, tidak tergantung dan siap dengan konsekuensi dari pilihan yang telah dibuat.

Peserta didik kelas IX SMP secara perkembangan berada pada masa remaja madya, karena berusia antara 15-18 tahun (Monks, dkk dalam Desmita, 2006.: 192). Hal ini berdampak pada kemampuan pembuatan keputusan karier yang dibuat oleh peserta didik kelas IX. Menurut Andehey \& Vandehey (2012: 296) individu remaja muda cenderung memiliki kemampuan membuat keputusan yang lebih rendah dari pada remaja yang lebih tua dan orang dewasa.

Menurut Super (Osipow: 1983: 10) keputusan karir yang memadai didasarkan pada kesamaan konsep diri individu dengan konsep vokasional yang dipilihnya. Sejalan dengan pendapat tersebut, Tiedeman dan Ohara (Sharf, 1992: 302) mengemukakan bahwa kemampuan pembuatan keputusan karier adalah suatu upaya untuk membantu individu menyadari semua faktor yang melekat dalam membuat keputusan sehingga mampu membuat pilihan yang tepat didasari oleh pengetahuan tentang diri dan informasi eksternal yang sesuai.

Hasil temuan pada tiap aspek kemampuan pembuatan keputusan karier mengungkapkan bahwa aspek pengetahuan dan aspek sikap secara umum berada pada kategori mampu, sedangkan untuk aspek keterampilan berada pada kategori cukup mampu.

Menurut Krumboltz (Sharf, 2010: 369) dalam membuat keputusan karier, perilaku atau tindakan dan kesadaran (mengetahui atau berpikir) adalah hal penting. Sejalan dengan pendapat tersebut Tiedeman dan Ohara (Sharf, 1992: 302) mengemukakan bahwa kemampuan membuat keputusan karir didasari oleh pengetahuan tentang diri dan informasi eksternal yang sesuai. Tiedeman dan Ohara lebih menekankan pada proses eksplorasi diri yang dilakukan individu dan informasi eksternal berupa lingkungan karier. Pertimbangan lingkungan karier sangat penting untuk keputusan karier bagi peserta didik, hal ini bertujuan agar pilihan karier yang ditentukan sesuai dengan diri.

Pembuatan keputusan karier menekankan perlunya sebuah keyakinan dan keterlibatan. Keyakinan merupakan sikap positif peserta didik dalam membuat keputusan karier yang berupa kepercayaan diri peserta didik (Supriatna, 2010: 56). Keterlibatan ditunjukan dengan aktivitas peserta didik dalam proses membuat keputusan karier, seperti berdiskusi dengan guru, orangtua, dan teman dalam rangka mencari informasi mengenai lingkungan karier.

Hasil temuan pada aspek keterampilan yang berada pada kategori cukup mampu dapat dipahami, karena menurut Sharf (1992: 157) keterampilan dalam membuat keputusan karier adalah kemampuan untuk menggunakan 
pengetahuan dan pemikirannya. Individu mampu meggunakan pengetahuan yang telah didapatkan berupa pengetahuan mengenai diri dan lingkungan karier. Sejalan dengan itu, Supriatna (2010: 57) mengemukakan:

"orangtua masih sangat dibutuhkan remaja dalam memberikan saran dan nasehat ketika hendak membuat keputusan yang bersifat jangka panang, yang penting tetpi sulit untuk dilakukan seperti keputusan tentang program pendidikan yang hendak ditekuninya,singkatnya dukungan orangtua masih sangat dibutuhkan oleh remaja dalam memutuskan rencana masa depannya"

Kemampuan pembuatan keputusan karier individu dapat dipengaruhi oleh faktor yang berasal dari diri dan luar diri individu. Patton dan McMahon (2001: 130) menyatakan bahwa kemampuan pembuatan keputusan dan perkembangan karier individu dipengaruhi oleh faktor dalam diri individu (internal) dan sosial masyarakat atau lingkungan dimana perkembangan karier terjadi (ekternal). Faktor-faktor tersebut berupa minat, kernampuan, ketemmpilan, bakat, nilai-nilai, keyakinan, konsep diri, kepribadian, orientasi seksual, status kesehatan, cacat, pengetahuan dunia kerja, usia, jenis kelamin, dan etnis.

Peran emosi dalam pembuatan keputusan karier seseorang adalah memberikan dorongan untuk bertindak dalam mencari peluang karier dan mengeliminasi karier yang tidak dihendaki oleh lingkungan (Young dkk., dalam Brown, George-Curran, \& Smith, 2003: 380). Kondisi emosi individu yang stabil akan mampu memberikan dorongan untuk membuat keputusan karier berdasarkan pertimbangan yang jelas tentang dirinya dan pilihannya.

Berdasarkan hasil penelitian yang didapatkan menunjukan bahwa terdapat kontribusi positif dan signifikan stabilitas emosi terhadap kemampuan pembuatan keputusan karier peserta didik kelas IX SMP Negeri 26 Bandung Tahun Ajaran 2016/2017. Artinya, keragaman skor kemampuan pembuatan keputusan karier peserta didik kelas IX SMP Negeri 26 Bandung Tahun Ajaran 2016/2017 salah satunya ditentukan oleh stabilitas emosi. Berdasarkan hasil analisis, apabila stabilitas emosi peserta didik meningkat maka kemampuan pembuatan kpeutusan karier mereka akan semakin baik.

Stabilitas emosi berkontribusi sebesar $16,7 \%$ dalam keragaman skor kemampuan pembuatan keputusan karier peserta didik kelas IX SMP Negeri 26 Bandung Tahun Ajaran 2016/2017, sedangkan sisanya sebesar 83,3\% ditentukan oleh faktor lain selain stabilitas emosi.

Berkaitan dengan hasil analisis penelitian, terdapat beberapa pendapat ahli dan penelitian-penelitian yang sesuai atau kesimpulannya saling mendukung. Fabio, dkk (2013) mengungkapkan bahwa stabilitas emosi berkontribusi 
sebesar $23 \%$ dalam variabel ketidaktegasan keputusan karier, faktor lainnya yang mempengaruhi adalah self-efficay, kepribadian, dan dukungan sosial. Sejalan dengan temuan tersebut, Young dan Valach (Brown, George-Curran, \& Smith, 2003: 380) mengungkapkan bahwa karier sangat terhubung dengan emosi, sehingga kesadaran emosi dalam pemahaman karier adalah hal yang penting. Hal ini sejalan dengan hasil penelitian yang menunjukan stabilitas emosi berkontribusi sebesar $16,7 \%$ terhadap kemampuan pembuatan keputusan karier, artinya bahwa selain faktor stabilitas emosi kemampuan pembuatan keputusan karier ditentukan oleh faktor lain seperti self-efficay, kepribadian, dan dukungan sosial.

Hal ini juga didukung oleh pendapat Cooper (Brown, George-Curran, \& Smith, 2003: 381) menjelaskan bahwa orang-orang yang mampu mengatur emosinya secara efektif dapat mencapai karier yang sukses. Peran stabilitas emosi dalam pembuatan keputusan karier peserta didik adalah sebagai pengendali dorongan dalam bertindak agar tidak membuat keputusan karier salah yang akan mengakibatkan kegagalan dalam pencapaian kariernya dimasa depan.

Hasil penelitian yang menunjukan bahwa terdapat hubungan yang positif dan signifikan antara stabilitas emosi dengan kemampuan pembuatan keputusan karier didukung oleh beberapa pendapat ahli. Pada saat peserta didik mengungkapkan dan memahami apa yang diinginkannya tentang keputusan pilihan sekolah lanjutan setelah SMP kepada orang tua, mampu menyesuaikan diri dengan pendapat dan keinginan orang tua tentang studi lanjutan, dan menghormati pendapat orang tua tanpa melukai perasaannya, maka peserta didik tersebut sudah memiliki emosi yang stabil dan mampu membuat keputusan karier yang sesuai.

Dillard (1985: 53) menjelaskan bahwa pembuatan keputusan merupakan usaha yang melibatkan perasaan, nilai, kecerdasan, komitmen, persepsi, dan informasi yang sesuai. Sebuah pilihan karier yang diputuskan secara baik tentunya akan menentukan meraih tujuan karier. Pendapat tersebut menegaskan bahwa stabilitas emosi termasuk kedalam bagian dari kemampuan individu dalam pembuatan keputusan karier.

Menurut Gadassi, Gati, \& Wagman-Rolnick (2013: 493) kendala emosi dapat menghambat dalam proses pembuatan keputusan karir seseorang. Stabilitas emosi dapat mempengaruhi kemampuan peserta didik dalam pembuatan keputusan karier, karena peserta didik akan sulit menyadari kemampuan dirinya dan cenderung mengikuti perintah orang lain karena merasa khawatir pilihan dirinya tidak seperti yang diharapkan.

Menurut Vandehey (2012: 295) kekurangan yang masih dimiliki remaja dibandingan dengan orang yang lebih dewasa dalam membuat keputusan 
karier adalah pengalaman, membuat keputusan yang impulsif, dan terbatasnya kemampuan dalam memproyeksikan konsekuensi yang diperoleh. Selain itu, persepsi teman sebaya, kondisi emosional remaja saat membuat keputusan, dan keingininan untuk mencoba-coba hal baru menjadi kelemahan peserta didik dalam membuat keputusan. Berdasarkan pendapat tersebut, keputusan karier tidak seluruhnya dibuat oleh peserta didik, tetapi tetap melibatkan orang dewasa lain seperti orang tua dalam membuat keputusan karena lebih memiliki pengalaman yang lebih dan sebagai role model karier yang baik.

Menurut Sharf (1992: 157) kemampuan individu membuat keputusan karier didasari oleh pengetahuan, sikap, dan keterampilan. Sharf memandang bahwa kemampuan dalam pembuatan keputusan karier adalah kemampuan dalam memahami informasi diri, dan informasi karier. Sikap dalam pembuatan keputusan karier merupakan aktivitas eksplorasi terhadap pilihan karier yang diharapkan. Keterampilan dalam membuat keputusan karier mengacu pada penggunaan pengetahuan dan pemikiran dalam membuat sebuah keputusan karier. Hal ini sejalan dengan pendapat Supriatna (2010: 15) yang menyatakan bahwa kemampuan individu untuk membuat pilihan secara tepat bukan kemampuan bawaan tetapi kemampuan yang dikembangkan. Apabila peserta

didik telah mempunyai pengetahuan berupa informasi yang memadai tentang pilihan studi lanjutannya dan sikap positif terhadap pilihan karier maka peserta didik sudah memiliki kemampuan dalam membuat sebuah keputusan karier yang tepat.

\section{SIMPULAN}

Gambaran umum stabilitas emosi peserta didik kelas IX SMP Negeri 26 Bandung Tahun Ajaran 2016/2017 berada pada kategori kurang stabil. Hal ini menunjukan emosi peserta didik kelas IX yang kurang stabil dan masih belum konsisten dengan sikap yang ditunjukan dalam kehidupan sehari-hari.

Gambaran umum kemampuan pembuatan keputusan karier peserta didik kelas IX SMP Negeri 26 Bandung Tahun Ajaran 2016/2017 berada pada kategori mampu. Hal ini menunjukan bahwa peserta didik kelas IX mampu mengetahui kemampuan dan kelemahan yang dimilikinya, memiliki keyakinan bahwa pilihan kariernya merupakan pilihan tepat, dan telah mampu menggunakan pengetahuan dan pemikiran dalam membuat keputusan serta bertanggung jawab atas keputusannya.

Stabilitas Emosi berkontribusi positif dan signifikan terhadap kemampuan pembuatan keputusan karier peserta didik kelas IX SMP Negeri 26 Bandung Tahun Ajaran 2016/2017. Nilai kontribusi stabilitas emosi terhadap kemampuan pembuatan keputusan karier sebesar 16,7\%. Hal ini berarti bahwa 
keragaman skor kemampuan pembuatan keputusan karier peserta didik kelas IX SMP Negeri 26 Bandung Tahun Ajaran 2016/2017 salah satunya ditentukan oleh stabilitas emosi. Dengan demikian, emosi peserta didik yang stabil tentunya juga akan membantu kemampuan pembuatan keputusan karier peserta didik.

Hasil penelitian menunjukan bahwa tingkat stabilitas emosi dan kemampuan pembuatan keputusan karier peserta didik kelas IX SMP Negeri 26 Bandung Tahun Ajaran 2016/2017 berada pada kategori kurang stabil dan mampu. Berdasarkan hasil analisis, kontribusi yang diberikan stabilitas emosi terhadap kemampuan pembuatan keputusan karier sebesar $16,7 \%$. Proses pembuatan keputusan karier harus dilakukan dengan baik oleh peserta didik khususnya kelas IX, karena akan berpengaruh terhadap kariernya dimasa depan. Berdasarkan hasil penelitian, maka guru bimbingan dan konseling dapat menggunakan data mengenai stabilitas emosi dan kemampuan pembuatan keputusan karier sebagai landasan dalam penyusunan layanan bimbingan dan konseling karier untuk meningkatkan kemampuan pembuatan keputusan karier yang tepat bagi kelas IX. Guru bimbingan dan konseling diharapkan dapat membina stabilitas emosi peserta didik agar kemampuan pembuatan keputusan karier dapat berkembang secara optimal, serta dapat mengembangkan kemampuan pembuatan keputusan karier peserta didik melalui faktor-faktor lainnya yang dapat mempengaruhi kemampuan pembuatan keputusan karier peserta didik.

\section{REFERENSI}

Ali, M., \& Asrori, M. (2009). Psikologi remaja. Bandung: Remaja Rosdakarya.

Arifin, Z. (2011). Evaluasi Pembelajaran. Bandung: Remaja Rosdakarya.

Badan Pusat Statistik. (2014). Tenaga Kerja. [Online]. Tersedia: https://www.bps.go.id/Subjek/view/id/6

Brown, C., George-Curran, R., \& Smith, M. L. (2003). The role of emotional intelligence in the career commitment and decision-making process. Journal of Career Assessment, 11(4), 379-392.

Budiamin, A.. (2002). Manajemen Layanan Bimbingan Karir Pada SMU Negeri di Kabupaten Bandung. Psikopedagogia: Jurnal Psikologi Pendidikan dan Bimbingan, 2, 259-266.

Chotimah, C. (2010). Hubungan Kestabilan Emosi dengan Prestasi Belajar Pada Siswa Kelas $X$ di SMA Negeri 1 Karanganom (Skripsi, UNS).

Desmita. (2013). Psikologi Perkembangan. Bandung: Remaja Rosdakarya. 
Dillard, J. M. (1985) Life Long Career Planning. Colombus Ohio: A Bell and Howell Company.

Dissanayake \& Gunaseakre, T. P. (2016). Emotional Stability: From The Buddhism Lens. Kolombo: Proseding Konferensi Internasional Akademik ke-13.

Fabio, A. D., Palazzeschi, L., Asulin-Peretz, L., \& Gati, I. (2013). Career indecision versus indecisiveness: Associations with personality traits and emotional intelligence. Journal of Career Assessment, 21(1), 42-56.

Gadassi, R., Gati, I., \& Wagman-Rolnick, H. (2013). The adaptability of career decision-making profiles: Associations with self-efficacy, emotional difficulties, and decision status. Journal of Career Development, 40(6), 490-507.

Gati, I., \& Saka, N. (2001). High School Students' Career-Related DecisionMaking Difficulties. Journal of Counseling \& Development, 79(3), 331340.

Hurlock, E. (2002). Psikologi Perkembangan (Suatu Pendekatan Sepanjang Rentang Kehidupan). Jakarta: Erlangga.

Irawati, D. (2003). Kontribusi Kestabilan Emosi Siswa Terhadap Penyesuaian Siswa di Sekolah (Skripsi, Universitas Pendidikan Indonesia, Bandung).

Iskandar, P. A. (2015). Program Bimbingan Karier Berdasarkan Profil Keputusan Karier Peserta Didik (Skripsi, Universitas Pendidikan Indonesia, Bandung).

Kartadinata, et al. (2013). Pedoman Penelusuran Minat Peserta Didik Sekolah Menengah Pertama. Jakarta: Direktorat Jenderal Pendidikan Dasar Kementerian Pendidikan dan Kebudayaan.

Latifa, R. (2012) Psikologi Emosi. [Online]. Tersedia: https://uinjkt.ac.id/renalatifa/articles/bab-4-psikologi-emosi-ekspresiemosi.

Lestari, M. (2015). Program Bimbingan Karir Untuk Mengembangkan Kemampuan Keputusan Karier Siswa (Penelitian Kuasi Eksperimen Terhadap Siswa Kelas IX di SMP Kartika XIX-2 Bandung Tahun Ajaran 2014/2015) (Tesis, Universitas Pendidikan Indonesia, Bandung).

Manrihu, M. T. (1988). Pengantar Bimbingan dan Konseling Karir. Jakarta: P2LPTK.

Murro, J. J., \& Kottman, T. (1995) Guidance and Counseling in the Elementary and Middle Schools: A Practical Approach. lowa: Brown Communication, Inc.

Osipow, S. H. (1983). Theories of Career Development. New Jersey: PrenticeHall Inc. 
Patton, W., \& McMahon, M. (2001). Career Development Program: A Preparation of lifelong career decision making. Australia: ACER.

Rachmaniar, A. (2015). Kontribusi Stabilitas Emosi dan Kontrol Diri Terhadap Kemampuan Pembuatan Keputusan Karier (Tesis, Universitas Pendidikan Indonesia, Bandung).

Ragasukmasuci, L. B. (2013). Program Bimbingan Karir Untuk Meningkatkan Kemampuan Pembuatan Keputusan Karier Peserta didik Sekolah Menengah Pertama (Skripsi, Universitas Pendidikan Indonesia, Bandung).

Sharf, R. S. (1992). Applying Career Development Theory of Counseling. California: Wadswort Inc.

Singh, D., Kaur, S., \& Dureja, G. (2012). Emotional maturity differentials among university students. Journal of Physical Education and Sport Management, 3(2), 41-45.

Sugiyono. (2014). Metode Penelitian Pendidikan. Bandung: Alfabeta.

Suherman, U. (2013). Bimbingan dan Konseling Karir: Sepanjang Rentang Kehidupan. Bandung: Riqzi Press.

Sukmadinata, N. S. (2013). Metode Penelitian Pendidikan. Bandung: Remaja Rosdakarya.

Supriatna, M. (2010). Layanan Bimbingan Karier di Sekolah (Edisi Revisi). Bandung: DPPB FIP.

Usman, H., \& Akbar, P. S. (2000). Pengantar Statistika, edisi revisi 2000. Jakarta: Bumi Aksara.

Widanti. (2015). Hubungan Antara Kestabilan Emosi dengan Problem Solving pada Mahasiswa Program Studi Psikologi Universitas Sebelas Maret Surakarta (Skripsi, Universitas Sebelas Maret, Solo).

Yuan, Z. W. (1998). Young People and Careers: School Career Guidance in Shanghai, Eidenburg, and Hongkong. Comparative Education Research Center The University of Hongkong.

Yulius, A. (2014). Kemantapan Pengambilan Keputusan Karir Siswa Kelas IX di SMP Negeri 9 Salatiga (Skripsi, Universitas Kristen Satya Wacana, Salatiga).

Yusuf, S. (2011). Psikologi Perkembangan Anak dan Remaja. Bandung: Remaja Rosda Karya.

Zamroni, E., Sugiharto, D. Y. P., \& Tadjri, I. (2014). Pengembangan Multimedia Interaktif Bimbingan Karir Untuk Meningkatkan Keterampilan Membuat keputusan Karir Pada program Peminatan Siswa SMP. Jurnal Bimbingan Konseling, 3(2), 130-136. 